\title{
A Study of the Causes of Famine in Iran during World War I
}

\author{
Mohammad Reza Pordeli ${ }^{1}$, Malihe Abavysany ${ }^{1}$, Maryam Mollashahi ${ }^{1} \&$ Doost Ali Sanchooli ${ }^{1}$ \\ ${ }^{1}$ Department of History, Zabol University, Zabol, Iran \\ Correspondence: Mohammad Reza Pordeli, Department of History, Zabol University, Zabol, Iran. E-mail: \\ M.mpordeli@uoz.ac.ir
}

Received: March 20, 2017

Accepted: April 1, 2017

Online Published: May 18, 2017

doi:10.5539/res.v9n2p296

URL: http://doi.org/10.5539/res.v9n2p296

\begin{abstract}
In the early twentieth century, for various political and economic reasons, the European countries were divided into the Allies and the Central Powers which led to the beginning of World War I. During those years, Iran was politically and economically too weak. Despite the fact that Iran declared neutrality in this war, it attracted the attention of world powers because of its vast oil resources and especial geographical location. In this way, Iran too was affected by the war. At the time Iran had lost its political independence due to certain colonial contracts (e.g., 1907, 1915). With the start of the war, a large group of foreign troops occupied Iran. This in fact was a heavy blow to the economics and agriculture of Iran, and together with the successive droughts, marked the most extreme famine of the century in Iran. Food shortage, high prices, disease contagions, and the pressure of the foreign forces to collect food supplies, increased the mortality rate so much so that almost half of the Iranian population died in dire conditions.
\end{abstract}

Keywords: Famine, Iran, World War I, England

\section{Introduction}

The colonialist countries began World War I in 1914 over having more economic and political dominance, a war which spread death and displacement during those four years. Despite the fact that Iran declared neutrality in the war, it was politically, economically, and socially affected by the presence of these hostile forces.

Undoubtedly, the first consequence of World War I for Iran was the famine in 1917-1918. This famine was unprecedented in its scope, affecting almost the whole country. The Iranian government was not able to handle the alarming situation and failed in helping the people. As a consequence, a lot of people died out of hunger. By the end of the famine, almost half of the population of Iran had died.

While there have been many books and articles about the First World War and its adverse effects on Iran, the topic of the famine remains understudied. Recent studies about the famine have not completely analyzed its different aspects and causes. This study tries to compensate for this gap.

The main aim of the present study is to examine the causes of famine in Iran during World War I. The economic and political conditions of Iran are also described by means of bibliographic research, rational deduction, and historical comparison. To be able to fully understand the scope of the famine, a brief discussion about the political and economic conditions of Iran is presented, followed by the many different causes of the famine.

\section{Method}

The study's method is descriptive — explaining, along with critical view is.

\section{Results}

\subsection{The Political Condition of Iran during World War I}

The foreboding years of 1871-1914 in Europe known as the Armistice were in fact the background for the rise of the First World War. It was during these years that the new colonial powers such as the Second Reich (Germany) was created, which then opposed the existing divisions of the strategic locations around the world. Trying to gain dominance over these locations was the next move. However, this ambition only led to the destruction of the previous relations (Mollaee, 1996, p. 52).

In such a condition, Germany, Austria, and Italy-known as the Allies—stood against France, England, and Russia - known as the Central Powers. Only a spark was enough to begin the war. In July 1914, with the murder 
of Crown Prince of Austria, Austria declared war on Siberia, leading to a worldwide war (Abbasi-Azizlu, 2013, p. 19).

The start of the First World War coincided with the recent (only eight days prior to the war) coronation of Qajar Ahmad Shah. Most historians content that the social and political conditions of Iran was not good at the time. This is also proven by recent studies. In these years, Iran had lost its political independency and according to an agreement (1907) was divided into three areas; two occupied by Russia and England, and one remained neutral (Sepehr, 1983, pp. 363-364). In 1915, things became worse. Under a new contract, the buffer zone itself was divided between Russia and England (Farmanfarmayan, 2003, p. 66).

In such a condition and given the King's courtiers and nobles awareness of the inadequacy of the military-mostly Cossack troops or the gendarmerie under the supervision of Russians and Swedes (Abbasi-Azizilu, 2013, p. 24) -it was natural for the government of Iran not to get involved in the war. The prime minister of the time, Mostofi al-Mamalek, declared the neutrality of Iran with regard to the war (Soltani-Shayan, 2011, p. 62).

However, the especial geopolitical location of Iran which had already become an important strategic zone for the Russians and English, drew the attention of the Allies too. As a result, Iran could no longer remain a neutral country. While the Central Powers did not intend to initiate a war in Iran, the Allies, especially Germany, practiced their policy of war in Iran. They believed that the war could get the Russians and English involved in strategic zones of Iran, and therefore disrupt the balance of the European battlefield (Mollaee, 1996, pp. 56-57).

As a result of the above policy, the Ottoman state, which was one of the main allies of Germany, violated the borders of Iran in 1914 to fight the Russians. This was the beginning of a long time of instability, killings, and pillage in Iran (ibid., p. 60).

The weakness of the central government in Iran prepared the ground for the invasion of foreign forces. Even some of the factions and groups within Iran began to support one of the two groups, especially the Germans. General hatred of the Russians and English in previous decades was the cause behind the supporting of the Germans, something which is reported by the German spies in their notes and diaries (Niedermayer, 2001, p. $65)$.

In the course of time, the number of foreign forces in Iran multiplied. Iran became the main battleground in the east. During the previous decades, Iran was always used as the military base of European countries under the title of the South Police. The social and economic situation exacerbated each day. Establishing such units as the South Police, which was purported to be for the security of the area, worsened the situation in reality. Most Iranians, especially southern tribes like Tangestani firmly opposed the English (Britons). There were even cases of jihad fatwa in the area against the English (Yahosseini, 1997, p. 104). Fighting the English by the tribes was strengthened when other tribes joined in, including: dalvari, chah-kutahi, boraz-jani, dashtestani, Qashqai, etc. (Farmanfarmayan, 2003, p. 74). This led to the killing of many residents of the region and created insecurity and famine.

It should be noted that these conflicts were not limited to the south and was spread across the country. One must mention the heroic resistance of Mirza Kuchik Khan in the north of Iran against the Russians. He had organized a small military force by the help of the local people and could resist the Russians for a long time (Sepehr, 1983, pp. 386-387).

A similar situation was going on in the west of Iran. The Ottoman forces continued fighting the Allied forces in Iran. In fact, they could reach the city of Hamedan in the early days of the ear (Ahrar, Bita, pp. 798-799). This affected the lives of the people and led to the killing of many and dislocation of many more.

The condition of the time disrupted the political, social, and military order of Iran. The central government was not able to manage the situation and establish order. The main problem of the central government was the lack of trained and armed troops for establishing order. In fact, maintaining security and order in Iran was assigned to the Russian Cossack brigade and the Swede troops in the gendarmerie (Abbasi-Azizilu, 2013, p. 24).

Accordingly, a government which was completely dependent on the power of foreign forces could not play any positive role in improving the conditions of the people. The government was not even able to defend the monarchy, and felt insecure by any threats. In one occasion during the war, Ahmad Shah Qajar changed the capital to Isfahan because of the threats made by the Russians and the inability of the Iranian government to defend Tehran (Farmanfarmanyan, 2003, pp. 38-39). This political condition was only one part of the chaotic disorder of the monarchy of the time. The consequences were extreme for the people, including, the famine during the war. 


\subsection{Causes and Consequences of the Famine}

The 1917-1918 famine in Iran, during World War I, is undoubtedly one of the most severe and devastating one in history. In a sense, it is no exaggeration to say that it was the famine in the twentieth century. The scope, extent, and severity of this famine was unprecedented. The famine was the result of various natural and political reasons, killing millions of the Iranians.

A look at the population of the time can describe the scope of this famine. According to many foreign reporters, including Russell, the Chief Prime Minister of Great Britain, and estimates from the elections of the time, the population of Iran in 1914 was between twenty to twenty one million people. In 1919, this number became 11 million. That is, almost half of the population had died in the meantime (Majd, 2008, pp. 85-86).

It is clear that this is one of the most catastrophic events of the twentieth century in Iran. However, it remains understudied. Even some historians have denied the scope of the event. The description of the famine by Iranian historiographers and foreign spies is an undeniable testimony to the reality and catastrophe of the famine. One can mention the diaries of Mirza Abol-Ghasem Khan Kahalzadeh who was eye witness to the famine in his youth. With regard to the extent and scope of the famine, he notes: "This famine had killed many people in Tehran. Corpses of the poor who had died out of hunger were strewn on the streets of Tehran. Food and bread was extremely rare" (Kahalzadeh, 1991, p. 294).

It should be noted that this catastrophe was not limited to Tehran. In fact, all over the country, people died as a consequence of the famine. Many of the chroniclers of the period, such as General Major Dnstrvy, an English spy, who travelled across the country, confirms the catastrophic scope of the famine (Major, 1983, p. 106).

The scope of the famine was so catastrophic that there even reports of cannibalism in the country. There was one case where a mother killed her own six-year old son out of hunger (ibid., p. 150). In such a dire condition, it is no surprise to hear about eating the meat of dogs and cats, or fighting over the corpse of an animal (Majd, 2008, p. 51).

In examining the causes of the famine, we can mention different factors which were directly or indirectly important in determining the scope and effects of the famine. One of the causes of famine in Iran was the lack of rain during 1917-1918 and the subsequent drought over a vast area of the country. One can also mention plant pests which decreased agricultural crops (Kuhestaninejad, 2002, p. 44).

It should be mentioned that the drought was not nation-wide. However, the incompetency of the government of the time and its failure in managing the situation led to further failures in helping the people of the country. Accordingly, it can be claimed the lack of a powerful central government incapable of managing the drought and the lack of suitable transport facilities and pathways were among other causes of the extremity of the famine (Moradinia, 2003, p. 49).

While the Iranian government tried to help the people in the face of the famine, given the dependency of the government on foreign forces, most of its activities were futile.

Accordingly, the presence of innumerable foreign forces in Iran can be considered as the most important crisis of the time and the main cause of the spread of famine, leading to further political and economic disorder. In fact, the presence of large troops of Ottoman, Russian, and English forces in Iran used up most of the food supplies. There are enough historical documents about the purchasing of wheat by these forces more than they needed (Kuhestaninejad, 2002, p. 44). There is some evidence about the fact that the English forces sent the wheat which they had bought from the Iranian to their own forces in Baku (Majd, 2008, pp. 142-143).

While the English could buy wheat and other grains from the neighboring countries, e.g., Mesopotamia and India, they exerted more pressure on the people of Iran in order to save time and buy the supplies with lower prices (ibid., p. 73).

There is also some historical evidence which shows that the hostile countries involved the war used the policy of scorched-earth, i.e., they burned up the supplies before they left a city in order to prevent the other side to access the supplies (ibid., p. 8). This is in fact another example of the hostility of the foreign countries against Iran.

It was natural to expect that such a trend would lead to the shortage of grain and the abuse of profiteers and speculators. The price of wheat increased $714 \%$ during the war (Torabi, 1991, p. 26). As a result, most people were unable to buy wheat.

As mentioned before, the government took certain measures to help the people. For example, it banned selling grain to the English for a period of time, and prescribed heavy fines for anyone who violated the ban (Major, 1983 , p. 124). In another instance, the government organized a group of people from among the benefactors to 
help the poor and therefore prevent the death of people out of hunger. A food called "dam-pokhtak" was prepared and distributed among the people. This year was known as the year of "dam-pokhtak" (Kuhestaninejad, 2002, p. 42).

These activities by the government were not very helpful because first of all the government was economically under a lot of constraints and could not continue helping the people. Also, it did not have the necessary independence to oppose the decisions made by the foreign forces. In fact, the foreign forces, especially the Russians and the English, had so much dominance on the internal affairs of the country that the Shah had to appoint or dismiss the prime minister with their permission (Kahalzadeh, 1991, pp. 26-27).

On the other hand, the English forces controlled the oil fields of Iran - the only source of national gross. The English did not pay their debts to Iran, controlled the oil fields, and had complete monopoly over them. Therefore, little of the oil money was given to the government of Iran (Majd, 2008, pp. 183-187).

The pressure of foreign forces on Iran was not limited to the above points. In one period, it was these forces, and not the government, that collected the tax paid by the people. They also had complete monopoly over the customs' revenue in Iran (Kahalzadeh, 1991, p. 19).

This catastrophic political, economic, and social condition continued until the end of World War I. As mentioned before, almost half of the population of Iran died. By the end of the war, and the victory of the Allies, the countries involved in the war divided their possessions and spoils of the war among themselves. Iran which despite its declaration of neutrality had suffered from the war and had lost a large number of its population prepared a fourteen-page document addressed to the "Preparatory Conference for Peace in Paris" to ask for compensations. However, this document did not mention many of the disasters in Iran as a consequence of war. The Iranians did not succeed in their plea for compensation in the Versailles Treaty either (Majd, 2008, pp. 212-213). The many injustices done to the people of Iran were buried in the heart of history.

\section{Discussion}

Given its strategic location and vast oil resources, Iran has always been at the center of attention of colonial countries, especially Russia and England. When World War I began, the Allies shifted the battleground into Iran to decrease the power of the Central Powers in the European front. This was a violation of the declaration of neutrality made by Iran.

The political and economic condition of Iran at the time was not stable. The government was not able to manage the crisis. A lot of damage was done to the country during the war. One of the most extreme and severe of these catastrophes was the famine of 1917-1918. This famine was the cause of the death of almost half of the population (20 million) of Iran.

While natural causes were important in creating this famine, one cannot ignore the presence of foreign forces and their destructive influence on the economy of Iran. Unfortunately, Iran was under the occupation of three forces at the time, i.e., Russia, England, and the Ottoman troops. They used up a large part of the country's supplies. They also adopted certain destructive policies, such as the scorched-earth policy, which justified the destruction of many urban facilities and supplies, adding to the severity of the famine. These foreign forces controlled the taxing system and in fact disabled the government in their efforts to help the people.

It is clear that the weakness of the central government of Iran was another cause of the severity of the famine. A powerful government could have prevented many of these catastrophes. However, the Qajar government was incapable of opposing the foreign forces and therefore failed in helping the people in such dire conditions.

As mentioned earlier, the set of these causes created the century's famine in Iran. However, it should be noted that the topic of famine has many other dimensions which go beyond the scope of the present article. Further studies should be done in the future to shed light on the dark corners of the famine in Iran to let the world know about the many injustices that have been done to the country of Iran.

\section{References}

Ahrar, A. (Bita). (n.d.). Hurricane in Iran (Vol. 2). Tehran: Novin.

Torabi, S. (1991). A Study of Provisions in Iran. Ganjine Asnad, 3, 4.

Major, D. (1983). British Imperialism in Iran and Caucuses (2nd ed., A. Hossein, Trans.). Ketabkhaneh Manuchehri.

Sepehr, M. D. (1983). Iran in the Great War 1914-1918 (2nd ed.). Adib.

Soltani-Shayan, A. (2011). Iran Disrupted by World War I. Monthly Book of History and Geography, 159. 
Abbasi-Azizlu, J. (2013). Iran in World War I. Journal of Teaching History, 35.

Farmanfarmayan, M. (Raees). (2003). The Life of Abdol-Hossein Mirza Farmanfarma (1st ed., Vol. 2).

Kuhestaninejad, M. (2002). The year of “dam-pokhtak” 1917. Ganjine Asnad, 5, 6.

Kahalzade, M. A. G. K. (1991). Memories and Diaries (2nd ed.). Alborz.

Majd, M. G. (2008). The Great Famine: 1917-1918 (K. Mohammad, Trans.). Center of Political Studies.

Moradinia, M. (2003). The Diaries of Seyyed Mohammad Komreie (1st ed., Vol. 1). Shirazeh.

Emlaee, A. (1996). The Place of Iran in the Military Plan of the Allies and the Central Powers in World War I. Panzdahe-Khordad, 3.

Niedermayer, O. (2001). Under the Burning Sun (1st ed.). Asatir.

Yahosseini, S. G. (1997). Raeis Ali Dalvari (1st ed.). Shirazeh.

\section{Copyrights}

Copyright for this articleis retained by the author(s), with first publication rights granted to the journal.

This is an open-access article distributed under the terms and conditions of the Creative Commons Attribution license (http://creativecommons.org/licenses/by/4.0/). 